\title{
Synthesis of Some Schiff's Bases Containing 1,3,4-Thiadiazole Ring and Their Properties as Antioxidants
}

Kahlan M. Abbas Al-Shammary

Department of Medical Chemistry, College of Medicine, Al Qadisiyah University, Iraq.

Abstract

A series of Schiff's bases containing 1,3,4-thiadiazole (2,5-di(N-substitutedbenzylideneamino)1,3,4-thiadiazole) were prepared through the reaction of thiosemicarbazide with chloro cyanide. The product was directly reacted with benzaldehyde and substituted benzaldehydes. The synthetic compounds (0-10) were identified using the analytical and spectral means. The antioxidant properties were measured of the prepared compounds using the metal ions $\left(\mathrm{Fe}^{+3}, \mathrm{Cu}^{+2}\right)$, and Ferrozine and 2,9-dimethyl-1,10-phenanthroline (neocuproine). The results showed that the compound no. 5 [2,5-di(N-(4-hydroxybenzylideneamino)-1,3,4-thiadiazole] reveals the highest antioxidant activity through this work.

\section{Introduction}

The progress achieved in the synthesis of heterocyclic compounds with a biological potential is due to improvement of the methodological study of tested substances too.

It is known that many 1,3,4- thiadiazole and 1,2,4-triazole derivatives have biological activity, with their antibacterial [1-3], antimycobacterial [4,5], antimycotic [6], antifungal [7,8], antidepressive [9], and cardiotonic [10] action being notable.

Recent research has also established for these heterocycles an analgesic [11] and antiinflammatory [12,13] activity. Meanwhile, Nacylated amino acids are known for their hepatoprotective [14], antimicrobial [15,16] and antitumoral $[17,18]$ action.

In the view of the facts mentioned above and as part of our initial efforts to discover potentially active new agents. Hence, it has been reported that 1,3,4-thiadiazole derivatives were widely used for their antioxidant activity [19].

\section{Experimentals and Methods}

The synthesis of the target molecule is shown in the sequences of reactions depicted in the following scheme. The FTIR spectral data were recorded on FTIR-8300 Fourier Transform Infrared Spectrophotometer SHIMADZU using potassium bromide disc. Double-beam UV-Visible spectrophotometer (UV $1650 \mathrm{CP}$ ), SHIMADZU. Melting points $\left({ }^{\circ} \mathrm{C}\right)$ were recorded on hot stage Gallen Kamp melting point apparatus and were uncorrected. Chemical names follow IUPAC nomenclature.


2,5-di(N-substitutedbenzylideneamino)-1,3,4-thiadiazole

Scheme. 
1) Synthesis of 2,5-diamino-1,3,4-

thiadiazole:

Thiosemicarbazide $(0.02$ mole $)$ was dissolved in $(50 \mathrm{ml})$ of absolute ethanol, chlorocyanide (0.02 mole) was added to this solution and the reaction mixture was refluxed for (6 hrs.)[20], the resultant solution was poured onto crushed ice, the solid obtained was filtered and recrystallized from ethanol, the yield was (60\%), the melting point was $\left(185{ }^{\circ} \mathrm{C}\right)$, the compound was directly used in the next step. The FTIR $\left(\mathrm{KBr} \mathrm{cm}^{-1}\right)$ spectral data for this compound are as follows 32103100 (asym. and sym. stretching vibration of $\mathrm{NH}_{2}$ group), $1620($ cyclic $\mathrm{C}=\mathrm{N})$.

2) Synthesis of 2,5-di(N-

substitutedbenzylideneamino)-1,3,4-

thiadiazole:

2,5-diamino-1,3,4-thiadiazole (0.01 mole) was dissolved in absolute ethanol $(50 \mathrm{ml})$, benzaldehyde or substituted benzaldehyde (0.01 mole) was slowly added to the refluxed mixture, the net mixture was refluxed for (7 hrs.) with stirring, the reflux was completed for another two hours until no more precipitate formed. After cooling to room temperature the mixture was filtered and the precipitate was dried and recrystallized from ethanol, the yield was $(60 \%)$, the melting point of the target molecule was $\left(190{ }^{\circ} \mathrm{C}\right)$. The same reaction was carried out to different substituted benzaldehyde $\left(\mathrm{G}: \mathrm{H}, p-\mathrm{Cl}, p-\mathrm{Br}, p-\mathrm{OCH}_{3}, p\right.$ $\mathrm{NO}_{2}, p-\mathrm{OH}, m-\mathrm{Cl}, m-\mathrm{Br}, m-\mathrm{OCH}_{3}, m-\mathrm{NO}_{2}, m-$ $\mathrm{OH})$. The FTIR $\left(\mathrm{KBr} \mathrm{cm}^{-1}\right)$ spectral data (stretching vibrations) for the compounds (0-10) are shown below in Table (1). The physical properties of the compounds (0-10) are shown in Table (2).

Table (1)

The FTIR $\left(\mathrm{KBr} \mathrm{cm}^{-1}\right)$ spectral data (stretching vibrations) for the compounds (0-10).

\begin{tabular}{|c|c|c|c|c|c|c|}
\hline$G$ & Compd. & $\mathrm{O}-\mathrm{H}$ & $\begin{array}{c}\text { C-H } \\
\text { aromatic }\end{array}$ & $\begin{array}{c}C-H \\
\text { aliphatic }\end{array}$ & $C=N$ & $\begin{array}{c}C=C \\
\text { aromatic }\end{array}$ \\
\hline $\mathrm{H}$ & 0 & - & 3070 & - & 1617 & 1608 \\
\hline$p-\mathrm{Cl}$ & $\bar{~} 1$ & $\overline{-1}$ & 3063 & $\overline{-1}$ & 1620 & 1567 \\
\hline$p-\mathrm{Br}$ & 2 & - & 3100 & - & 1627 & 1588 \\
\hline$p-\mathrm{OCH}_{3}$ & 3 & - & 3105 & 2933-2794 & 1634 & 1590 \\
\hline$p-\mathrm{NO}_{2}$ & 4 & - & 3100 & - & 1620 & 1590 \\
\hline$p-\mathrm{OH}$ & 5 & 3382 & 3082 & - & 1625 & 1600 \\
\hline$m-\mathrm{Cl}$ & $\overline{66}$ & - & 3030 & - & 1616 & $\overline{1571}$ \\
\hline$m-\mathrm{Br}$ & 7 & - & 3007 & - & 1620 & 1587 \\
\hline$m-\mathrm{OCH}_{3}$ & 8 & - & 3020 & $2950-2805$ & 1623 & 1600 \\
\hline$m-\mathrm{NO}_{2}$ & 9 & - & 3034 & - & 1629 & 1603 \\
\hline$m-\mathrm{OH}$ & 10 & 3360 & 3042 & - & 1612 & 1602 \\
\hline
\end{tabular}


Table (2)

The melting point and yield of the compounds (0-10).

\begin{tabular}{|c|c|c|c|c|}
\hline $\boldsymbol{G}$ & Compd. & $\begin{array}{l}M . P . \\
\left({ }^{o} C\right)\end{array}$ & $\begin{array}{c}\% \\
\text { Yield }\end{array}$ & IUPAC Name \\
\hline $\mathrm{H}$ & 0 & $190-192$ & 80 & 2,5-di(N-benzylideneamino)-1,3,4-thiadiazole \\
\hline$p-\mathrm{Cl}$ & 1 & $192-194$ & 75 & 2,5-di(N-(4-chlorobenzylideneamino)-1,3,4-thiadiazole \\
\hline$p-\mathrm{Br}$ & 2 & $203-205$ & 70 & 2,5-di(N-(4-bromobenzylideneamino)-1,3,4-thiadiazole \\
\hline$p-\mathrm{OCH}_{3}$ & 3 & $188-190$ & 84 & 2,5-di(N-4-methoxybenzylideneamino)-1,3,4-thiadiazole \\
\hline$p-\mathrm{NO}_{2}$ & 4 & $197-199$ & 66 & 2,5-di(N-(4-nitrobenzylideneamino)-1,3,4-thiadiazole \\
\hline$p-\mathrm{OH}$ & 5 & $210-212$ & 82 & 2,5-di(N-(4-hydroxybenzylideneamino)-1,3,4-thiadiazole \\
\hline$m-\mathrm{Cl}$ & 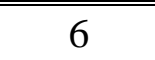 & $177-179$ & 65 & 2,5-di(N-(3-chlorobenzylideneamino)-1,3,4-thiadiazole \\
\hline$m-\mathrm{Br}$ & 7 & $191-193$ & 71 & 2,5-di(N-(3-bromobenzylideneamino)-1,3,4-thiadiazole \\
\hline$m-\mathrm{OCH}_{3}$ & 8 & $185-187$ & 77 & 2,5-di(N-(3-methoxybenzylideneamino)-1,3,4-thiadiazole \\
\hline$m-\mathrm{NO}_{2}$ & 9 & $198-200$ & 81 & 2,5-di(N-(3-nitrobenzylideneamino)-1,3,4-thiadiazole \\
\hline$m-\mathrm{OH}$ & 10 & $203-205$ & 88 & 2,5-di(N-(3-hydroxybenzylideneamino)-1,3,4-thiadiazole \\
\hline
\end{tabular}

3) Ferric ion $\left(\mathrm{Fe}^{+3}\right)$ antioxidant properties:

The antioxidant properties of the prepared compounds containing 1,3-oxazoline ring reduce $\left(\mathrm{Fe}^{+3}\right.$ to $\left.\mathrm{Fe}^{+2}\right)$ were measured by using ferrozine [21]. The reduction of $\left(\mathrm{Fe}^{+3}\right)$ by 1,3-oxzoline was studied at $\mathrm{pH} 5.5$, due to low solubility of iron at physiological $\mathrm{pH}$, the reaction mixture contained $50 \mathrm{mM}$ sodium acetate buffer ( $\mathrm{pH} 5.5$ ). $1 \mathrm{mM}$ ferrozine, 50, $100 \mu \mathrm{M}$ of tested compounds and $100 \mu \mathrm{M}$ of $\mathrm{Fe}\left(\mathrm{NO}_{3}\right)_{3}$. The reaction was started by the addition of $\mathrm{Fe}\left(\mathrm{NO}_{3}\right)_{3}$ and the increase of absorbance at $562 \mathrm{~nm}$ after 3 minutes was recorded, $\mathrm{Fe}^{+2}$ concentration was determined by using an extinction coefficient for $\mathrm{Fe}$ (ferrozine $)_{3}{ }^{+2}$ complex which is equal to $27.9 \times 10^{3} \mathrm{M}^{-1} . \mathrm{cm}^{-1}[22]$.

\section{4) Copper ion $\left(\mathrm{Cu}^{+2}\right)$ antioxidant properties:}

The antioxidant properties of the prepared compounds containing 1,3-oxazoline ring reduce $\left(\mathrm{Cu}^{+2}\right.$ to $\left.\mathrm{Cu}^{+1}\right)$ were measured by using 2,9-dimethyl-1,10-phenanthroline (neocuproine) [23], an indicator molecule that binds specifically to the reduced form of copper $\left(\mathrm{Cu}^{+1}\right.$ but not to the oxidized form $\mathrm{Cu}^{+2}$ ) [24]. The reaction mixture contained (20 $\mathrm{mM}) \quad \mathrm{KH}_{2} \mathrm{PO}_{4} / \mathrm{KOH}$ buffer ( $\mathrm{pH} 7.4$ ), $200 \mu \mathrm{M} \mathrm{Cu}\left(\mathrm{NO}_{3}\right)_{2}, 600 \mu \mathrm{M}$ 2,9-dimethyl-1,10phenanthroline, $50,100 \mu \mathrm{M}$ of the tested compounds.

The mixtures were incubated at room temperature for 120 minutes and then the absorbances were recorded at $455 \mathrm{~nm}$. The copper concentration was determined by using an extinction coefficient for $\mathrm{Cu}$ (neocuproine) ${ }_{2}{ }^{+2}$ complex which is $7.2 \times$ $10^{3} \mathrm{mM}^{-1} . \mathrm{cm}^{-1}$, that was determined by reducing $\mathrm{Cu}^{+2}$ with ascorbate [23].

\section{Results and Discussion}

The synthesis of 2,5-di(Nsubstitutedbenzylideneamino)-1,3,4thiadiazole was achieved by the reaction of thiosemecarbazide with chloro cyanide in absolute ethanol, the product was reacted with benzaldehyde and substituted benzaldehyde to form the target molecules (0-10). The authenticity of the product was confirmed by spectral data (FTIR) shown in Table (1). The antioxidant properties of the prepared 
compounds are assessed by the extent of conversion of the $\mathrm{Fe}^{+3}$ and $\mathrm{Cu}^{+2}$ to the reduced form $\mathrm{Fe}^{+2}$ and $\mathrm{Cu}^{+1}$ ).

The antioxidant properties of the compounds were studied at different concentrations. The antioxidant activity of putative antioxidant has been attributed to various mechanisms, among which are prevention chain initiation, binding of transition metal ion catalyst, decomposition of peroxides, prevention of continued hydrogen abstraction, reductive capacity and radical scavenging [25]. The compound (5) reveals the highest antioxidant activity this is attributed to the presence of hydroxyl group in the $p$-position of the benzene ring. Thiadiazoles (0-10) studied show higher reducing capacity for copper ions than for iron ions, this can be attributed to the standard reduction and oxidation potentials of the metals, the standard reduction potential of the $\mathrm{Cu}^{+2} / \mathrm{Cu}^{+1}(0.15 \mathrm{~V})$ which is much lower than that for $\mathrm{Fe}^{+3} / \mathrm{Fe}^{+2}(0.77 \mathrm{~V})$. Table (3) and Table (4) show the antioxidant properties of compounds (0-10).

Note the standard deviation (SD) referred to $( \pm)$ of at least three independent experiments was calculated and showed in the results.

Table (3)

The antioxidant values of compounds (0-10) against $\mathrm{Fe}^{+2}$.

\begin{tabular}{|c|c|c|c|}
\hline \multicolumn{4}{|c|}{ umole $\mathrm{Fe}^{+2} /$ mmole 1,3,4-thiadiaozle } \\
\hline Compd. & $G$ & $50 \mu M$ & $100 \mu M$ \\
\hline 0 & $\mathrm{H}$ & $0.0075 \pm 0.001$ & $0.0058 \pm 0.001$ \\
\hline 1 & $p-\mathrm{Cl}$ & $0.0052 \pm 0.001$ & $0.0010 \pm 0.001$ \\
\hline 2 & $p-\mathrm{Br}$ & $0.0042 \pm 0.000$ & $0.0028 \pm 0.001$ \\
\hline 3 & $p-\mathrm{OCH}_{3}$ & - & $0.0023 \pm 0.000$ \\
\hline 4 & $p-\mathrm{NO}_{2}$ & $0.0031 \pm 0.001$ & $0.0019 \pm 0.002$ \\
\hline 5 & $p-\mathrm{OH}$ & $0.0330 \pm 0.002$ & $0.0500 \pm 0.001$ \\
\hline 6 & $m-\mathrm{Cl}$ & $0.0023 \pm 0.001$ & $0.0018 \pm 0.001$ \\
\hline 7 & $m-\mathrm{Br}$ & $0.0029 \pm 0.001$ & $0.0010 \pm 0.001$ \\
\hline 8 & $m-\mathrm{OCH}_{3}$ & $0.0040 \pm 0.002$ & $0.0012 \pm 0.001$ \\
\hline 9 & $m-\mathrm{NO}_{2}$ & $0.0045 \pm 0.003$ & $0.0032 \pm 0.000$ \\
\hline 10 & $m-\mathrm{OH}$ & $0.0090 \pm 0.000$ & $0.0294 \pm 0.001$ \\
\hline
\end{tabular}


Table (4)

The antioxidant values of compounds (0-10) against $\mathrm{Cu}^{+1}$.

\begin{tabular}{|c|c|c|c|}
\hline \multicolumn{4}{|c|}{ umole $\mathrm{Cu}^{+1} / \mu m o l e$ 1,3,4-thiadiazole } \\
\hline Compd. & $G$ & $50 \mu M$ & $100 \mu M$ \\
\hline 0 & $\mathrm{H}$ & $0.20 \pm 0.001$ & $0.33 \pm 0.000$ \\
\hline 1 & $p-\mathrm{Cl}$ & $0.23 \pm 0.001$ & $0.36 \pm 0.001$ \\
\hline 2 & $p-\mathrm{Br}$ & $0.38 \pm 0.000$ & $0.51 \pm 0.001$ \\
\hline 3 & $p-\mathrm{OCH}_{3}$ & $0.49 \pm 0.002$ & $0.62 \pm 0.002$ \\
\hline 4 & $p-\mathrm{NO}_{2}$ & $0.25 \pm 0.003$ & $0.43 \pm 0.002$ \\
\hline 5 & $p-\mathrm{OH}$ & $0.68 \pm 0.001$ & $0.90 \pm 0.001$ \\
\hline 6 & $m-\mathrm{Cl}$ & $0.08 \pm 0.001$ & $0.18 \pm 0.001$ \\
\hline 7 & $m-\mathrm{Br}$ & $0.18 \pm 0.004$ & $0.31 \pm 0.001$ \\
\hline 8 & $m-\mathrm{OCH}_{3}$ & $0.31 \pm 0.001$ & $0.44 \pm 0.000$ \\
\hline 9 & $m-\mathrm{NO}_{2}$ & $0.21 \pm 0.004$ & $0.32 \pm 0.002$ \\
\hline 10 & $m-\mathrm{OH}$ & $0.39 \pm 0.001$ & $0.56 \pm 0.001$ \\
\hline
\end{tabular}

\section{Reference}

[1] Varvarason, A.; Tantili-Kakoulidou, A.; Siatra-Papastasikoudi, T.; Tiligada, E. Synthesis and biological evaluation of indole containing derivatives of thiosemicarbazide and their cyclic 1,2,4triazole and 1,3,4-thiadiazole analogs. Arzneim. Forsch., 50, 48-54, 2000.

[2] Gokce, M.; Cakir, B.; Earl, K.; Sahin, M. Synthesis and antimicrobial activity of [(2-oxabenzothiazolin-3-yl)-methyl]-4alkyl/aryl-1, 2, 4-triazoline-5-thiones. Arch. Pharm., 334, 279-283, 2001.

[3] Pintilie, O.; Profire, L.; Sunel, V.; Popa, M.; Pui, A. Synthesis and antimicrobial activity of some new 1,3,4-thiadiazole and 1,2,4-triazole compounds having a D, Lmethionine moiety. Molecules, 12, 103113, 2007.

[4] Faroumadi, A.; Mirzaei, M.; Shafiee, A. Synthesis and antituberculosis activity of 2-ary 1-1,3,4- thiadiazole derivatives. Pharmazie, 56, 610-612, 2001.
[5] Mamolo, M.G.; Falagiani, V.; Zanpier, D.; Vio, L.; Banfi, F. Synthesis and antimycobacterial activity of [5-(pyridin-21,3,4-thiadiazol-2-yl-thio)]-acetic acid arylidene - hydrazide derivatives. Farmaco, 56, 587-592, 2001.

[6] Zamani, K.; Faghifi, K.; Tefighi, I.; Sharlatzadeh, R. Synthesis and potential antimycotic activity of 4-substituted 3(thiophene-2-yl-methyl)- $\Delta 2-1,2,4-$

triazoline - 5-thiones. Turk. J. Chem., 28, 95-101, 2004.

[7] Zan, X.I.; Lai, L.H.; Jin, G.Y.; Zhong, Z.X. Synthesis, fungicide activity and 3DQSAR of 1,3,4-oxadiazoles and 1,3,4thiadiazoles. J. Agric. Food Chem., 50, 3757-3760, 2002.

[8] Chem. H.; Li, Z.; Han, Y. Synthesis and fungicidal activity against Rhizoctonia solani of 2-alkyl(alkylthio)-5-pyrazolyl1,3,4-oxadiazoles (thiadiazoles). J. Agric. Food Chem., 48, 5312-5315, 2000.

[9] Clerici, F.; Pocar, D.; Guido, M.; Loche, A.; Perlini, V.; Brufoni, M. Synthesis of 2- 
amino-5-sulphonyl-1,3,4-thiadiazole derivatives and evaluation of their antidepressant and anxiolytic activity. $J$. Med. Chem., 44, 931-936, 2001.

[10] Onkol, T.; Cakir, B.; Sahin, M.F. Synthesis and antinociceptive activity of 2[(2-oxabenzothiazolin-3-yl)-methyl]-5aminoalkyl/aryl-1,3,4-thiadiazole. Turk. $J$. Chem., 28, 461-466, 2004.

[11] Shenone, S.; Bruno, O.; Ranise, A.; Bondavalli, W.; Falcone, G.; Giordano, L.; Vitelli, M. 3-Arylsulphonyl-5-arylamino1,3,4-thiadiazol-2(3H)ones as antiinflammatory and analgesic agents. Bioorg. Med. Chem., 9, 2149-2153, 2001.

[12] Labanauskas, L.; Kalcas, V.; Uderenaite, E.; Gaidelis, P.; Brukstus, A.; Dauksas, V. Synthesis of 3-(3,4-dimethoxyphenyl)-1H1,2,4-triazole-5-thiol and 2-amino-5-(3,4dimethoxyphenyl) $\quad-1,3,4-\quad$ thiadiazole derivatives exhibiting anti-inflammatory activity. Pharmazie, 56, 617-619, 2001.

[13] Palaska, E.; Sahin, G.; Kelincen, P.; Durlu, N.T.; Altionax, G. Synthesis and anti-inflammatory activity of 1-acyl thiosemicarbazides, 1,3,4-oxadiazoles, 1,3,4-thiadiazoles and 1,2,4-triazole-3thiones. Farmaco, 57, 101-107, 2002.

[14] Sunel, V.; Lionte, C.; Popa, M.; Pintilie, O.; Mungiu, P.; Teleman, S. Synthesis of new methionine derivatives for the treatment of paracetamol-inducet hepatic injury. Eur. Chem. Tech. J., 4, 201-205, 2002.

[15] Pintilie, O.; Sunel, V.; Profire, L.; Pui, A.; Synthesis and antimicrobial activity of some new (sulfonamidophenyl)-amides of $\mathrm{N}$-(metanitrobenzoyl)-D, L-methionine. Farmacia, 55, 345-251, 2007.

[16] Moise, M.; Sunel, V.; Profire, L.; Popa, M.; Lionte, C. Synthesis and antimicrobial activity of some new (sulfon-amidophenyl) - amide derivatives of $\mathrm{N}$-(4-nitrobenzoyl)phenylglycine and N-(4-nitrobenzoyl)phenylalanine. Farmacia, 56, 283-289, 2008.

[17] Sunel, V.; Lionte, C.; Basu, C.; Cheptea, C. New antitumour alkylating compounds with N- [m- (arylthiocarbamoyl)aminobenzoyl] - asparagic acids support. Chem. Indian J., 2, 1-6, 2005.
[18] Sunel, V.; Popa, M.; Desbrieres, J.; Profire, L.; Pintilie, O.; Lionte, C. New di( $\beta$-chloroethyl) $-\alpha$-amides on $\mathrm{N}$ - (macylaminobenzoyl)- D, L- aminoacid supports with antitumoral activity. Chem. Indian J., 4, 1-8, 2005.

[19] Pattan SR, Kittur BS, Sastry BS, Jadhav SG, Thakur DK, Madamwar SA, Shinde HN. Synthesis and evaluation of some novel 1,3,4-thiazoles for anti-diabetic activity. Indian J. Chem.; 50B: 615-618, 2011.

[20] British Patent, 916, 016 (1963), chem. Abs. 59, 1650 (1963).

[21] Lurdes, M.; Fernandez, M. T.; Santos, M.; Rocha, R.; Florêncio, M. H.; Jennings, K. R., Free Rad. Res., 36, 1199-1208, 2002.

[22] Stooky, L. L., Anal. Chem., 42, 779-781, 1970.

[23] Proudfoot, J. M.; Croft, K. D.; Puddey, I. B.; Beilin, L. J., Free Rad. Biol. Med., 23, 720-728, 1997.

[24] Simpson, J. A.; Narita, S.; Gieseg, S.; Gebicki, J. M; Dean, R. T., Biochem. J., 282, 621-624, 1992.

[25] Yildirim, A.; Mavi, A.; Kara, A. A., J. Agri. Food Chem., 49, 4083-4089, 2001.

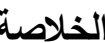

تم في هذا البحث تحضير مركبات (قواعد شف) مرتبطة

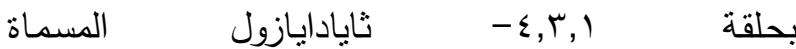

[2,5-di(N-substitutedbenzylideneamino)-1,3,4thiadiazole] كلورو سايانيد والناتج تمت مفاعلته بعد ذلك مع البنزالديهايد

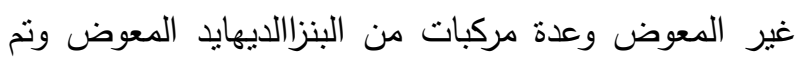
تتخيص المركبات بالوسائل التحليلية والطيفية، وتم قياس فعالية هذه المركبات (·-. • (1) كمضادات للأكسدة بأستخدام أيونات وذلك بأستخدام كاثف الفيروزين و

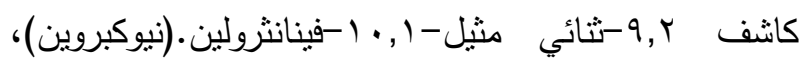

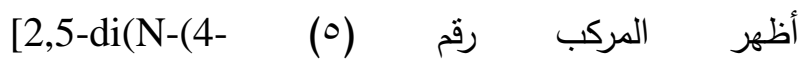
hydroxybenzylideneamino)-1,3,4-thiadiazole] أعلى فعالية كمضاد للأكسدة من خلال هذا البحث. 